\title{
Б.Н. БЕССОНОВ
}

Московский городской педагогический университет, Москва, Россия

\section{Аннотация}

Среди неомарксистов выделяется «франкфуртская философскосоциологическая школа», выступившая с претензией на восстановление аутентичного учения К. Маркса и его развитие применительно к реальной действительности XX в., в противовес ленинизму, восточному варианту марксизма, приспособленному Лениным для отсталых стран. Самые яркие представители этой школы - Т. Адорно, М. Хоркхаймер, Г. Маркузе и др.

Одним из широко распространенных приемов «возращения» к аутентичному марксизму является противопоставление «раннего» и «зрелого» Маркса, так, в частности, Маркузе доказывает, что Маркс наиболее аутентично изложил свою гуманистическую теорию в «Экономическофилософских рукописях 1844 г.» и что в «Капитале» гуманистическая проблематика якобы отодвинута на второй план. Апеллируя к «молодому» Марксу, Маркузе подменяет реальные классовые противоречия в экзистенциалистском духе абстрактно-антропологическими противоречиями между сущностью и существованием человека. Он, в сущности, искажает понимание К. Марксом отчуждения, интерпретирует его как всечеловеческий, антропологический феномен и выводит из него «катастрофу человека». Будущее общество выводится им не из понимания Марксом сущности человека как совокупности общественных отношений, а из сущности человека, который воспринимается как изолированный, объективно ничем и никак не обусловленный субъект, что, безусловно, приводит к отказу от понимания К. Марксом (и марксизмом в целом) диалектики общества и личности, их развития и преобразования на базе объективных исторических закономерностей.

Бессонов Борис Николаевич - доктор философских наук, профессор кафедры философии и социальных наук Института гуманитарных наук и управления Московского городского педагогического университета.

philos-mgpu@mail.ru

jani-house@mail.ru

Цитирование: БЕССОНОВ Б.Н. (2018) Карл Маркс. Его идеи и дела переживут века! Часть II // Философские науки. 2018. № 4. С. 62-79. DOI: $10.30727 / 0235-1188-2018-4-62-79$. 
К. Маркс не был утопистом. Во-первых, он никогда не составлял рецепты создания будущего, а досконально изучал историю экономики и в самой экономике, в экономических отношениях искал средства для разрешения социальных конфликтов, для движения от капитализма к новому, коммунистическому обществу. Конечно, в оценке Марксом (Энгельсом, Лениным, их последователями) перспектив краха капитализма есть момент абсолютизации. Марксу было присуще сужение временного горизонта капитализма, он недооценивал его жизнеспособность. Но ведь, он анализировал современное ему капиталистическое общество, которое тогда казалось в весьма малой степени жизнеспособным. Поскольку производительные силы продолжали неудержимо развиваться, социальные противоречия все больше углублялись и обострялись. Конец капитализма казался естественно необходимым и неизбежно скорым. Маркс, как и Энгельс, Ленин, не смог должным образом осознать способности буржуазии приспособиться к будущей научно-технической революции, не мог в полной мере учесть возможных изменений в структуре рабочего класса.

Более того, приспосабливаясь к обстоятельствам, капитализм существенным образом изменился. Многие черты, свойственные «старому» капитализму, сегодня, по сути дела, превратились в свою противоположность. Даже в реализации ряда социальных программ развитые капиталистические страны достигли большего, нежели страны «реального социализма».

Но опровергает ли все это вывод К. Маркса об исторически преходящем характере капитализма, о его эксплуататорской сущности? Посмотрим, например, на теорию обнищания трудящихся, разработанную К. Марксом, вокруг которой сейчас ведется так много дискуссий. В свете современной ситуации в развитых капиталистических странах тенденция к абсолютному обнищанию трудящихся, предсказанная Марксом и Энгельсом в «Коммунистическом Манифесте», не подтвердилась. Но ее ограниченность заметил и сам К. Маркс. В «Капитале» он уже указывает на возможность поднятия уровня реальной зарплаты в рамках капиталистической системы. Он подчеркивает, что рабочие не допускают понижения ее абсолютного минимума, a, наоборот, вынуждают буржуа предоставлять им некоторое участие в «росте общего богатства» [Маркс, Энгельс, т. 26, ч. III, 324]. 
тельно от объективно возможного, разве сумели бы они добиться того, что сейчас имеют?

Может быть, мысль М. Вебера о том, что возможного нельзя добиться, если не дерзать достигнуть невозможного, в данном случае особенно справедлива? Может быть лозунг «новых левых» в 70-е гг. ХХ в. «Будьте реалистами, требуйте невозможного» был вполне оправдан?

Безусловно, больше не должно быть «измов», нельзя превращать марксизм в сакральное учение. Но безусловно также, остаются методология К. Маркса, теоретический анализ истории капитализма, коммунизма. Примечательно, что многие проблемы мы и сегодня решаем в духе Маркса, хотя и заявляем, что он эти проблемы не мог предвидеть. Действительно, разве поиск решения глобальных проблем не идет сегодня в конечном счете в русле Марксовой методологии? Ведь так или иначе он направлен, во-первых, на перераспределение богатств как естественных, так и искусственных (включая и информацию), во-вторых, на расширение контроля со стороны общественности за деятельностью государства, вообще любой власти, в-третьих, на самоопределение индивидов.

Конечно, на ряд вопросов будущего развития Маркс не мог ответить с детальной точностью. Что такое «полугосударство» и «негосударство» в становящемся социалистическом обществе? В чем суть социалистической демократии? В свете нашей истории, истории других стран остро встает вопрос: насколько адекватно соответствует современным требованиям вывод о диктатуре пролетариата? Маркс говорил о коммунистическом обществе как об ассоциации свободных производителей, овладевших общественными отношениями. Но как конкретно складываются эти ассоциации, как организуются, как взаимодействуют? На все эти вопросы ответ, разумеется, в то время и не мог быть дан. Это не могло быть задачей Маркса, ибо не было практического «материала» для осмысления.

В любом случае учение Маркса, ставящее своей целью освобождение человека, гуманизацию человеческой жизни и деятельности, укрепляет, увеличивает шансы человечества выжить и жить в соответствии с принципами свободы, социального равенства, солидарности и справедливости.

\section{ЦИТИРУЕМАЯ ЛИТЕРАТУРА}

Ленин 1969 - Ленин В.И. Полн. собр. соч. Т. 37. - М.: Издательство политической литературы, 1969. 
Маркс, Энгельс - Маркс К., Энгельс Ф. Соч. 2-е изд. - М.: Государственное издательство политической литературы, 1955-1981.

\title{
KARL MARX. HIS IDEAS AND DOINGS WILL LIVE CENTURIES!
}

\author{
B.N. BESSONOV \\ Moscow City Pedagogical University, Moscow, Russia
}

\section{Summary}

The article analyzes the main ideas of Marx and Engels on the essential processes characterising the historical development of societies. The author shows that it is scientifically untenable to contrast the views of Marx and Engels on the ability to learn the laws of natural and social development. Marx and Engels are great scientists and revolutionaries. They turned socialism from utopia to science. Marxism discovered the main law of historical development: the law of equivalence of production relations to the charachter and development level of productive forces. Marxism proved that the main contradiction of capitalism is the contradiction between the social character of production and private character of product appropriation. Marx was certainly right in his understanding of the main processes of capitalist development. He gave the fighters against capitalist exploitation and oppression a model of the socialist society, which will inevitably establish itself as an alternative to capitalism, a society, where life will be characterized by labour, freedom, equality, justice, solidarity and peace. The author is convinced that Marx's theory is deeply scientific. Yet he does not say that one can find there all the answers to the questions of modern historical development. The experience of millions and time will show us the way. We need to study that experience, and check the reality against our ideals, without ever adjusting it to some forever established postulates.

Keywords: K. Marx, Marxism, neo-Marxism, socialism, utopia, philosophical materialism, humanism, dialectics.

Bessonov, Boris - D.Sc. in Philosophy, Professor at the Department of Philosophy and Social Sciences, Institute of Humanities and Management, Moscow City Pedagogical University.

philos-mgpu@mail.ru

jani-house@mail.ru

Citation: BESSONOV B.N. (2018) Karl Marx. His Ideas and Doings will Live Centuries. Part II. In: Philosophical Sciences. 2018. Vol. 4, pp. 62-79. DOI: 10.30727/0235-1188-2018-4-62-79.

\section{REFERENCES}

Lenin V.I. (1969) Omnibus Edition. Vol. 37. Publishing House of Political Literature, Moscow (in Russian).

Marx K., Engels F. Works (Russian Translation, $2^{\text {nd }}$ edition: State Publishing House of Political Literature, Moscow, 1955-1981). 